International Background Paper

Wealth Tax Commission

\title{
Wealth taxation in Switzerland
}

Authors

Jean-Blaise Eckert Lukas Aebi

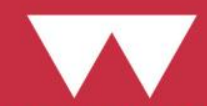




\section{WEALTH TAXATION IN SWITZERLAND}

Jean-Blaise Eckert, Lenz \& Staehelin, Switzerland

Lukas Aebi, Lenz \& Staehelin, Switzerland

Wealth Tax Commission Background Paper no. 133

Published by the Wealth Tax Commission

www.ukwealth.tax 


\section{Acknowledgements}

The Wealth Tax Commission acknowledges funding from the Economic and Social Research Council (ESRC) through the CAGE at Warwick (ES/L011719/1) and a COVID-19 Rapid Response Grant (ES/V012657/1), and a grant from Atlantic Fellows for Social and Economic Equity's COVID-19 Rapid Response Fund. 


\section{Historical Background}

Switzerland is well known to be one of the few countries to levy a general wealth tax ('impôt sur la fortune', 'Vermögenssteuer', 'imposte sulla sostanza').

A wealth tax was first introduced in Switzerland during the time of Helveticism (1789-1803) when Switzerland was a centralised uniform state with a centralised tax system. After the collapse of Helveticism, the cantons regained tax autonomy. Accordingly, cantonal tax systems developed quite differently: while some cantons returned to levying (only) indirect taxes (in particular custom duties, regalia, such as salt rights, etc.) as in the period before Helveticism, others retained the taxes levied in the Helvetic system, in particular the wealth tax.

In 1848, when the Swiss Federal State (Swiss Confederation) was founded, the Swiss tax system changed fundamentally: only the newly created Swiss Confederation was competent to levy customs and the cantons saw themselves forced to find alternative tax sources to compensate for the loss of tax revenue, namely the taxation of wealth and income. Until the First World War, a political understanding existed that the main tax revenue source of the Swiss cantons were direct taxes, whilst indirect taxes in the form of customs duties formed the backbone of the federal tax revenue. Depending on the canton, direct taxes were levied on wealth in the form of movable and/or immovable property as well as on income.

In response to budget shortfalls due to the First World War, the Swiss Confederation was in 1915 accorded the competence to levy one-time war taxes, inter alia, a wealth tax with maximum tax rates of $0.15 \%$ on the wealth of individuals. This wealth tax was accompanied by a wage tax, and for the first time the Swiss Confederation itself levied a direct tax. Due to the further budget constraints caused by the First World War and subsequently, the Second World War, the Swiss Confederation continued to levy direct taxes. The one-time war tax of 1915 was re-enacted in 1919 and levied six times during the 1920s and early 1930s. After the Great Depression, the Swiss Confederation again levied from 1934 to 1938 a crisis tax, which was, however, mainly an income tax. It also levied a supplementary wealth tax with maximum tax rates of $0.25 \%$. From 1941 to 1958 , the Swiss Confederation levied an income tax at rates of up to $6.5 \%$ with supplementary wealth tax of up to $0.35 \%$. The federal wealth tax was abolished in 1959 for individuals (and the federal capital tax on corporate equity was abolished in 1998).

The cantons continue to levy wealth taxes today. However, in the course of the $20^{\text {th }}$ century the cantons successively reduced the wealth tax and increased the income tax. Thus, today income taxes have become the main source of tax revenue for the cantons.

Politically, there have been a series of (rather fringe) parliamentary initiatives at the Swiss federal level to abolish or reform the wealth tax but none of them were successful. In general, the wealth taxation regime as such is respected in Switzerland and no major effort to abolish or fundamentally reform the Swiss wealth tax has been made in the last two decades. A motion filed in 2019 in the Swiss federal parliament calls for the Swiss Federal Council to elaborate a reform project which would abolish the Swiss wealth tax and introduce a capital gains tax with a maximum rate of $10 \%$ on private assets (cf. section 4.1, below). The Federal Council has recommended that the Parliament reject this motion and we think it is likely that this motion, which in an unconstitutional way limits the competences of the cantons to set their own tax rates (cf. section 2, below), will be rejected by the Swiss federal parliament. 


\section{Allocation of taxation competences between jurisdictions within Switzerland}

The Swiss Federal Constitution allows the Swiss cantons to exercise all (tax) competences not explicitly exclusively reserved for the Swiss Confederation (Article 5). The Swiss Confederation itself may only levy a tax if the Swiss Federal Constitution explicitly allows it to do so.

Furthermore, the Swiss federal constitution authorises the Swiss Confederation to legislate principles on the harmonisation of direct taxes, including wealth taxes, regarding (i)tax liability, (ii) tax object and tax period, (iii) procedural rules and (iv) criminal tax law. Although the Swiss Confederation has accordingly important harmonisation competences concerning cantonal wealth taxes, it may not harmonise tax rates. Based on its constitutional authority, the Swiss Confederation has enacted the Federal Act on the Harmonisation of Direct Taxes of Cantons and Municipalities, which requires the cantons to levy a wealth tax and provides inter alia for specific rules regarding the object of the wealth tax and valuation.

The legal framework thus requires the cantons to levy a wealth tax (albeit the tax rate may be close to 0\%). The Swiss Confederation, on the other hand, due to the lack of explicit constitutional authorisation, is precluded from doing so. All 26 cantons levy a wealth tax.

However, since the cantons are free to set wealth tax rates, the minimum and maximum cantonal wealth tax rates, the tax rate schedule, and accordingly, the tax burden can vary greatly between the cantons (cf. section 0 , below). Furthermore, a series of cantons tax certain assets differently, e.g. they levy an additional tax on certain forms of the holding of real estate (as does Geneva) or they lower the wealth tax rate on qualifying shareholders in closely held companies (as does Nidwalden). 


\section{Taxable basis}

\subsection{In general}

Swiss resident individuals are as a matter of principle subject to wealth tax on their worldwide assets (unlimited wealth tax liability). Individuals are Swiss resident if they either (i) have their domicile in Switzerland or (ii)spend without significant interruption (a) at least 30 days for work purposes or (b) 90 days for non-work purposes in Switzerland. Wealth tax is due from the first day of residency until the end of said residency, and is levied on a pro rata temporis basis in the case of arrival or departure during the year. The canton, in which the taxpayer is resident or, in the case of real estate, in the canton where the real estate is located, levies the wealth tax.

In principle, all asset classes are subject to wealth taxation. Hence, real estate, including private residences, all types of securities, including shares of private companies and all other moveable assets, including e.g. works of art, jewellery, vehicles, etc. are subject to the cantonal wealth taxes. Important exemptions apply to personal household items and to claims on pension fund payments and assets invested in recognised personal pension schemes, which are not subject to wealth tax.

The cantonal wealth taxes are assessed on a net basis, i.e. a taxpayer may deduct all personal liabilities from the wealth tax base. Although theoretically there is no difference in the deduction system for debt against Swiss real estate whether held by Swiss residents or nonresidents, in certain key practical aspects differences do arise and in some cases a mortgage debt incurred on real estate in Switzerland may be virtually non-deductible for a non-resident.

All cantons have a general wealth tax allowance of between 70,000 Swiss francs and 200,000 Swiss francs depending on the canton (see section 8).

Although married couples are each a separate tax subject, their wealth is added together to determine the applicable wealth tax rate. However, even though a majority of cantons has progressive wealth tax rates, not all cantons provide married taxpayers with a reduced tax rate. For example, the canton of Geneva does not distinguish between single and married taxpayers, whereas the canton of Zürich does (cf. section 0, below). Last, the net assets of minor children are also included in the parent's wealth tax base. The source of the minor child's wealth is irrelevant. The wealth of the child is attributed to the parent who has legal guardianship over the child if the parents are separated. Where the parents both have legal guardianship, the wealth is attributed to the parent with whom the child lives most of the time. The wealth tax due on the minor child's wealth can be funded out of that child's wealth. ${ }^{1}$

\subsection{Swiss international wealth taxation}

With regards to international taxing rights, the cantonal wealth tax regimes unilaterally exclude from the tax base assets attributable to foreign businesses or permanent establishments and real estate situated abroad, although these elements are taken into account for determining the

\footnotetext{
1 In December 2019, the Swiss Federal Parliament sent back a current reform project for the taxation of families to the Federal Council, so that the Federal Council may rework its project. The reform proposed by the Federal Council envisaged an 'alternative tax calculation'. The tax administration would start by determining the married couple's tax as in the case of ordinary joint taxation. It would then proceed to a second tax calculation (alternative calculation) based on the individual taxation of the cohabiting couple. The lower of the two amounts calculated according to these methods would be used.
} 
applicable wealth tax rate. This unilateral exemption applies regardless of whether the respective foreign jurisdiction levies a wealth tax or not.

Conversely, the Swiss cantonal tax codes provide for the wealth taxation of the (net) assets of foreign-resident individuals that are attributable to businesses or permanent establishments in Switzerland as well as foreign-owned Swiss real estate. In the case of a foreign resident individual holding Swiss-based assets (e.g. real estate) indirectly, e.g. through an opaque special purpose vehicle, the foreign individual would not be subject to the wealth tax anymore, but the special purpose vehicle would be subject to the cantonal capital tax (cf. section 4.2, below) on its net equity. The applicable tax rates depend on the worldwide net assets of such person. No wealth tax is levied in the case of a foreign-resident individual owning movable assets located in Switzerland (e.g. funds deposited with a Swiss bank) that are not attributable to a Swiss business or permanent establishment.

Furthermore, 63 of Switzerland's tax treaties include a provision covering wealth taxes, typically modelled after Article 22 of the OECD Model Convention.

Swiss resident individuals that emigrate to another jurisdiction are not subject to an exit tax or any kind of tail for wealth tax purposes. There are no special rules for arrivers other than nonSwiss citizens who opt to be taxed on a lump-sum basis (so called forfait). Note that some of those cantons, which have abolished the forfait, are among the cantons with the highest maximum wealth tax rates.

Where one spouse is resident and one is not, then the two are regarded as separate tax subjects and only the Swiss resident is subject to tax although the wealth of both spouses will be taken into account in determining the wealth tax rate.

\subsection{Valuation}

The relevant moment for valuing assets is the end of each tax period (i.e. annual valuation), or in the case of the tax liability ending during the year, at the end of the tax liability.

The federal harmonisation rules only provide broad guidelines concerning valuation: nonbusiness assets must be valued at market value (without defining market value) and for business assets the tax book values are relevant. Hence, the cantons in principle have some flexibility with regards to valuation.

The value of private companies is determined each year by the cantonal tax authorities based on an inter-cantonal administrative guideline agreed upon by the cantonal tax departments. Taxpayers may challenge the application of this guideline in court but appeals are rarely successful (cf. an example in section 0 , below). In case the fair-market value of operational companies cannot easily be assessed (e.g. because of lack of recent sales between independent third parties), their value is determined according to the formulaic method, called the practitioner's method. A company's value is determined by calculating the weighted average of its 'earnings value' and its net asset value (i.e. fair market value of assets minus liabilities), thereby counting the earnings value twice. The earnings value is determined by capitalising the adjusted average net profit of the last two or three years with a capitalisation rate (of currently $7 \%)$, which applies uniformly to all industries. Holding companies or real-estate companies are valued based on the net asset value of the underlying assets. 


\section{Example:}

Net asset value of Company X: 5 million Swiss francs

Adjusted net profit 2018: 750,000 Swiss francs

Adjusted net profit 2019: 600,000 Swiss francs

Adjusted net profit 2020: 700,000 Swiss francs

Average adjusted net profit 2018 - 2020: 683,333 Swiss francs

Earnings value: CHF 683'333 / 7\% = 9.7619 million Swiss francs

Company value: $(9.761$ million * $2+5$ million / $3=8.1746$ million Swiss francs.

The practitioner's method is often criticised because the strong weight given to the earnings value, combined with the (at least for some industries) rather high capitalisation rate leads to results that are far above from what a shareholder could actually realise, should he sell his equity investment to a third-party. The above-mentioned administrative guidelines include several provisions for addressing such issues. The most important ones are (i) in the case the value of a company is essentially dependent on a single person the earnings value is only weighted once instead of twice and (ii) in the case of minority shareholding, the value of the shares calculated according to the practitioner's method may be reduced by up to $30 \%$.

With regards to the valuation of real estate, the Cantons apply different methods.

In the Canton of Geneva, for example, the tax code provides that an expert commission assesses real estate values of each principal residence all ten years. In practice however, instead of the periodical re-evaluation, the previous tax value is merely increased at annual intervals by a certain factor. A tax allowance, which takes into account the length of time lived in the principal residence, reduces the taxable basis of the wealth tax. Investment properties, defined as real estate with more than two rentable units, are valued by capitalising the rental income based on a capitalisation rate which depends on the specific zone in which the building is located.

In the Canton of Zurich, the real estate value of principal residences is determined using a formula valuation. If the formula value is higher than $100 \%$ or lower than $70 \%$ of the market value (determined by either a recent purchase or a valuation by an independent expert), the tax value is determined on an individual basis. In the Canton of Zurich, investment properties are valued by capitalising rents based on a fixed capitalisation rate of $7.05 \%$. 


\section{Relation with other taxes}

\subsection{Income tax}

Both the Swiss Confederation and the Swiss cantons (and depending on the canton, the municipalities) levy a general income tax with maximum tax rates, depending on the canton, of between $22.3 \%$ and $46 \%$. Investment income is not subject to special, lower, tax rates with the exception of dividends received from at least $10 \%$ shareholdings in corporations, which are included to only $70 \%$ in the income tax base. No canton provides for a mechanism that allows wealth tax to be credited against income tax and as a general rule taxes are not deductible from the income tax base. Hence, taxpayers with a large fortune that yields relatively low returns may be subject to a significant aggregate tax burden of both income and wealth tax on investment returns. Some cantons have developed special regimes to deal with this issue (cf. section 5.1, below).

A special feature of the Swiss tax regime is that virtually all capital gains realised on the sale of non-business assets are exempt from both the federal as well as the cantonal (and communal) income tax. As an exception, capital gains realised on the sale of real estate or of majority stakes in real estate companies are subject to a special cantonal real-estate gains tax. Some may argue that the wealth tax may be seen as a counterpart to the lack of a capital gains tax in Switzerland, since the wealth tax allows the assets of a person to be taxed (like a capital gains tax) albeit not upon their realisation, but annually. Naturally, the lack of a capital gains tax incentivises taxpayers to realise the increased value of an asset through a sale and puts immense pressure on the distinction between taxable income and tax-exempt capital gains. This is a particular issue for closely held companies where controlling shareholders forego the possibility to payout dividends in order to realise the value of their equity through a sale. Liquidity is thereby managed by loans between the shareholder and the company. Several specific anti-abuse rules exist in this regard.

Charitable gifts are deductible from the wealth tax base only in the sense that the net wealth of the taxpayer at the end of the year will be lower where he has made charitable gifts.

\subsection{Capital tax}

The counterpart to the wealth tax for individual taxpayers is the capital tax at the level of corporations. The capital tax is also a cantonal tax, with tax rates ranging from $0.001 \%$ to $0.525 \%$ and is levied on the net equity of a Swiss corporation (exempting foreign permanent establishments and non-Swiss real estate), with approximately half of the cantons allow to credit corporate income tax paid against the capital tax. Swiss thin capitalisation rules apply also for Swiss capital tax purposes.

In sum, one may argue that the return on equity invested by a Swiss resident individual is thus taxed fourfold: on the corporate level with the capital tax and the corporate income tax (since dividends are not deductible for corporate income tax purposes) and at the level of the individual taxpayer with the wealth tax and the income tax. 


\subsection{Inheritance and gift tax}

The inheritance and gift tax is levied at cantonal level only; the Confederation does not levy an inheritance or gift tax. All cantons except the cantons Schwyz and Obwalden levy inheritance and gift taxes.

Since no federal harmonisation rules exist, the cantonal inheritance and gift taxes differ quite significantly. However, the following general points may be made: the tax base is usually levied at level of the heirs or donees and depends on the amount received. No canton levies inheritance tax on transfers to spouse and only three cantons (Lucerne, Neuchâtel and Vaud) on transfers to children. Furthermore, all cantons exempt contributions to charitable or public organisations from the inheritance and gift tax. The tax rates regularly depend on the familial relationship between the testator or donor and the heir or donee, ranging up to $54.6 \%$ (in the canton of Geneva) in the absence of family relationships.

Since no inheritance or gift tax is levied on transfers to spouse, to children or to charitable organisations, the scope of the Swiss inheritance and gift taxes is in practice quite narrow, compared to other countries. This may also be the reason why no Canton allows paid wealth taxes to be credited against inheritance or gift taxes. 


\section{Specifics}

\subsection{Tax shelters (bouclier fiscal; Vermögenssteuerbremse)}

In the canton of Geneva, where the maximum wealth tax rate of approximately $1 \%$ is the highest in Switzerland, the problem of what the jurisprudence and scholarship call confiscatory taxation arises: in certain situations, the combined income and wealth tax burden of a taxpayer may be so great that it infringes on his fundamental right of guarantee of property.

For this reason, the Geneva tax code has a mechanism known as the tax shield (bouclier fisca), which limits combined tax burden of the income tax and capital tax to $60 \%$ of net taxable income.

The tax codes of four other cantons include similar mechanisms. In all other cantons the only relief a taxpayer may seek is to appeal the tax assessment arguing that it violates his constitutionally protected right of property and is thus an unconstitutional confiscatory taxation. However, the thresholds for a successful argumentation of confiscatory taxation are exceedingly high (cf. section 0 , below).

\subsection{Trusts and Foundations/usufructs ${ }^{2}$}

Swiss law does not attribute legal personality to trusts, a legal concept foreign to Swiss civil law and only integrated through the ratification of the 1985 Hague Trust Convention.

The taxation of a trust depends first on its nature and second on the tax residency of the settlor. Again, cantonal peculiarities may exist, but the following general rules apply although it should be noted that what follows below is a simplification:

(a) A revocable trust is treated as transparent and its assets continue to be allocated to the settlor, to the extent that the settlor is not considered to be divested of the trust's assets.

(b) If an irrevocable discretionary trust is settled by a Swiss resident settlor the trust assets continue to be attributed to the settlor.

(c) However, where a settlor settles an irrevocable discretionary trust before immigration to Switzerland, the trust's assets are not attributed to the settlor (or the beneficiaries) for Swiss wealth tax purposes even after the settlor takes residency in Switzerland.

(d) As and when capital distributions are made from a discretionary trust to Swiss resident beneficiaries, their personal wealth is then increased for Swiss wealth tax purposes. But if say the trust is an irrevocable discretionary trust with a deceased settlor and say one Swiss and nine UK resident beneficiaries, it is only the actual distributions received by the Swiss beneficiary that are potentially subject to wealth tax on the Swiss beneficiary (as they have increased his personal wealth).

(e) Special rules may be attributed to Swiss real estate owned by a trust.

\footnotetext{
${ }^{2}$ Note that the Swiss tax law has not codified the taxation of trusts. An administrative circular issued by the Swiss Conference of Tax Directors provides some basic guidelines, but for many questions there is no clear answer and the tax consequences will depend on the facts of the specific case and the administrative practice in the respective canton.
} 
(f) The assets of an irrevocable fixed interest trust are allocated to the Swiss resident beneficiaries, based on their respective shares. If no allocation can be determined, the income that a Swiss resident beneficiary derives from an irrevocable fixed income trust is capitalised for wealth tax valuation purposes.

In Swiss civil law foundations are characterised as a complex of assets with own legal personality designated to serve a specific purpose. Swiss tax law also treats Swiss foundations as separate entities and as such they are subject to the capital tax and the corporate income tax, in the case they do not qualify as tax-exempt charitable or public entities. Swiss foundations have neither owners nor members so the net assets of a foundation are not subject to the wealth tax.

Where a Swiss resident person settles assets into the foundation such transfer is taxed for gift tax purposes as a donation to a third party and therefore subject to the highest applicable gift tax rates. However, transfers to certain tax-exempt entities, inter alia charitable organisations, are exempt from Swiss gift tax.

If a non-Swiss resident person settles assets into a Swiss foundation the assets are ignored for Swiss wealth tax purposes. However, the foundation is subject to the Swiss capital tax on its net equity as shown in its financial statements, insofar as the Swiss foundation is not a tax-exempt entity (e.g. a charitable organisation).

In the case of a usufruct, the beneficiary of the usufruct is liable for wealth taxes. If resident $A$ in Switzerland transfers to his son B (resident say in Austria) a securities portfolio but A and B agree that $A$ has a lifelong usufruct on the securities portfolio, $A$ will continue to be liable for Swiss wealth tax on the securities portfolio. Note though that if in the above example $A$ transfers his Swiss house to his son B but they agree informally that A can live in the house free of rent for the rest of his life, A will in principle not be subject to Swiss wealth tax on the property any more but B will be (cf. section 3.2. concerning the limited Swiss tax liability of non-Swiss resident taxpayers).

\subsection{Start-ups}

The shares of start-up companies are valued for wealth tax purposes according to the valuation methods described above. This will initially not lead to a significant tax burden as the start-up does not generate profits. However, in the case of successful investment round some cantons (in particular Zurich) have had the practice that the valuation paid by the investors was also relevant for determining the value of the founders' shares. In the case of a highly valued (but still unprofitable) start-up, this could put a significant tax burden on the founders and lead to serious liquidity concerns.

The cantons have found different solutions to deal with this problem. The canton of Zurich, for example, has the practice that the shares of start-ups (defined as companies with an innovative and scalable business model) are valued based on the net asset value of the start-up during the initial growth phase. 


\section{Enforcement and assessment}

Swiss wealth tax is assessed on an annual basis, together with Swiss income tax. A Swiss individual taxpayer files a combined income and wealth tax declaration, in which he is required to declare all his assets and the income derived therefrom. There is no lower threshold below the exemption threshold for reporting. Since the wealth tax return is part of the income tax return, the combined return has to be filed in any case, even if no taxes are due. While in principle each account/asset has to be reported separately, and a new list of assets has to be filed each year, much will depend on the individual circumstances and practices of the competent cantonal tax administration. For securities portfolios, banks prepare Swiss tax reports that already include all the relevant information for income and wealth tax purposes.

Two questions are often cause for litigation. First, naturally, the valuation of assets, in particular of shares in privately held companies, works of art and real estate. Second, the question of what qualifies as household items, which are excluded from the wealth tax base. In a widely discussed case, the Zurich administrative court ruled some years ago that a Giacometti painting that was sold for 2 million Swiss francs did not qualify as a household item, even if it was hung in the kitchen.

For Swiss residents wealth tax is difficult to avoid with standard tax planning techniques since trusts (with the exception of irrevocable fixed interest trusts) settled by a Swiss resident are disregarded for Swiss wealth tax purposes and passive investment companies are essentially also valued based on a look-through approach. Holding assets through an unincorporated business abroad might be a viable option but the threshold for creating an actual 'investment business' abroad is quite high and might create negative social security consequences in Switzerland. Furthermore, the relatively low tax rates usually reduce the incentive for excessive tax planning. Last, in the case of structures which (i) do not make any operational or economic sense, (ii) are put in place solely for the purpose of tax savings and (iii) would effectively lead to significant tax savings, the tax authorities may disregard the transaction in applying Swiss tax law's general anti-avoidance rule.

The automatic exchange of information based on the multilateral competent authority agreement and the common reporting standard, which Switzerland has ratified in 2015, with information being exchanged for the first time in 2018 , has greatly increased tax compliance, as shown e.g. by the fact that assets of roughly 5 billion Swiss francs were voluntarily disclosed in the canton of Zurich during 2016 - 2019, compared to roughly 3 billion of assets during 2012 2015.

Tax authorities also appreciate the fact that the wealth tax requires individuals to annually report their net wealth. The annual fluctuations in net wealth, together with statistical data on annual spending of individuals and households, allow the tax authorities the check the plausibility of the taxpayer's declared income. Thus, one may argue that the wealth tax also has a control function for income tax purposes.

The taxpayer may amend his tax return until the tax assessment of the respective year has entered into force, which, depending on the complexity of the tax return is usually between one to two years after the end of the respective tax period. The tax authorities may open enquiries/supplementary assessments within ten years after the tax period for which the tax assessment was made.

Payment dates are a matter of cantonal tax law. In general, provisional payments are required on account during the respective tax period or in the following tax period. There is no withholding from banks. 


\section{Case law}

There are not too many Swiss Supreme Court cases concerning the wealth tax. In the 1970s and 1980s the Swiss Supreme Court decided a series of cases regarding confiscatory taxation (cf. section 5.1, above), one of which is briefly discussed below. Today, wealth tax litigation typically focusses on the valuation of assets, as described below by two further cases.

In the Swiss Supreme Court case BGE 106 la 342 (1980), a taxpayer who owned a substantial minority stake in a privately held company appealed to the Swiss Supreme Court arguing confiscatory taxation. He argued that since the company had not paid out a dividend in the particular calendar year (despite being profitable), his combined income and wealth tax burden exceeded his net income for the respective year. Hence, the combination of income and wealth taxation led to an unconstitutional confiscatory taxation. The Swiss Supreme Court confirmed that in principle the fundamental right of property precludes a wealth tax from being confiscatory in nature, which is the case when the taxpayer has to dispose of the property (or parts thereof) itself to satisfy his wealth tax liability. However, the Swiss Supreme Court also held that a confiscatory taxation would only be admitted in the most extreme circumstances. ${ }^{3}$ In the case at hand, the company made a significant profit but did not pay out a dividend in the relevant tax year. Since the accumulated earnings increased the value of the shares, the Court held that the fundamental right to the guarantee of property was not necessarily violated. In the present case the Supreme Court held that the taxation was not confiscatory, even though the combined income and wealth tax liability in the present case exceeded the taxpayer's taxable income, since this happened only in a single tax period. For a taxation to be confiscatory, the tax infringement must be lasting, i.e. continue over several years.

In a more recent decision published in 2019 (2C_277/2018), which is a typical example of current litigation in Swiss wealth tax matters, the Swiss Supreme Court addressed the question of the validity of the above discussed administrative guideline (cf. section 3.3, above) on the valuation of unlisted securities. The taxpayer in question was a tax advisor who was the sole shareholder of an incorporated tax consulting business. The Swiss Supreme Court first held that the practitioner's method is in principle a valid and practical method to determine the fair market value of unlisted shares and the tax authorities had not violated the law by applying this method. Second, the tax administration also confirmed that in the case at hand the earnings value may only be weighted once (instead of twice) since it was obvious that the value of the tax advisory business depended primarily on the work of its shareholder. However, the taxpayer requested the value of the shares for wealth tax purposes to be even further reduced, arguing that the annual profit, which is necessary to calculate the earnings value, should be adjusted to take extraordinary circumstances into account. The Swiss Supreme Court rejected this argument stating that the taxpayer failed to demonstrate how exactly the circumstances referred to were extraordinary.

In a decision published this year (2C_66/2020), the Swiss Supreme Court examined the question of whether deferred real estate gains taxes on rental property located in Geneva should be deducted from real estate value for wealth tax purposes, which was determined according to the cantonal practice described above (cf. section 3.3). The Swiss Supreme Court rejected the taxpayer's appeal. The court held that only actually existing debts could be deducted and not merely latent, possible future debts, like a tax on real estate gains that were only due in the event of a future sale.

\footnotetext{
${ }^{3}$ In a prior case regarding income taxation in 1976 (BGE 102 la 220) the Swiss Supreme Court found that the taxpayer had to devote two thirds of his income to settle his income and wealth tax liability of the current tax period to not be confiscatory.
} 


\section{Numbers}

The Swiss Federal State has limited statistics on wealth tax, since no wealth tax is levied at the federal level. However, statistics for 2017 indicate that wealth tax from all cantons and their municipalities earned a total of 7.329 million Swiss francs. In total wealth tax made up a proportion of $3.8 \%$ of the total tax revenue of the Swiss public authorities (confederation, cantons and municipalities) in $2017^{4}$.

As mentioned in section 2, the cantons are free in setting their wealth tax rates. Furthermore, in most cantons the municipalities also levy a wealth tax (typically as multiplier of the cantonal wealth tax), which is usually assessed and collected together with the cantonal wealth tax. Hence, wealth tax rates are far from uniform and vary significantly between the cantons and even between different municipalities within a canton.

For example, in the canton of Geneva, which is considered to be the canton with the highest wealth tax rates in Switzerland, the bands and tax rates of the cantonal wealth tax are as follows:

\begin{tabular}{|l|l|}
\hline \multicolumn{1}{|c|}{ Band (Net wealth, Swiss francs (CHF)) } & Marginal tax rate \\
\hline CHF 1 - CHF 111,059 & $0.175 \%$ \\
\hline CHF 111,060 - CHF 222,117 & $0.225 \%$ \\
\hline CHF 222,118 - CHF 333,176 & $0.275 \%$ \\
\hline CHF 333,177 - CHF 444,234 & $0.300 \%$ \\
\hline CHF 444,235 - CHF 666,352 & $0.325 \%$ \\
\hline CHF 666,353 - CHF 888,469 & $0.350 \%$ \\
\hline CHF 888,470 - CHF 1,110,586 & $0.375 \%$ \\
\hline CHF 1,110,587 - CHF 1,332,703 & $0.400 \%$ \\
\hline CHF 1,332,704 - CHF 1,665,879 & $0.425 \%$ \\
\hline CHF 1,665,878 - & $0.450 \%$ \\
\hline
\end{tabular}

However, both a supplementary cantonal wealth tax and the municipal wealth tax must be added, to determine the actual wealth tax liability of taxpayer. The maximum wealth tax rate, including the supplementary cantonal wealth tax and the municipal wealth tax, is approximately $1 \%$ in the canton of Geneva.

In the canton of Zurich, the cantonal wealth tax rates and bands are as follows:

\begin{tabular}{|l|l|l|}
\hline \multicolumn{1}{|c|}{ Band I (Single taxpayers) } & $\begin{array}{c}\text { Band II (Married taxpayers, single } \\
\text { taxpayers with minor children) }\end{array}$ & \multicolumn{1}{|c|}{$\begin{array}{c}\text { Marginal wealth } \\
\text { tax rate }\end{array}$} \\
\hline CHF 1 - 77,000 & CHF 1 - 154,000 & $0 \%$ \\
\hline CHF 77,001 - CHF 308,000 & CHF 154,001 - CHF 385,000 & $0.05 \%$ \\
\hline CHF 308,001 - CHF 694,000 & CHF 385,001 - CHF 770,000 & $0.1 \%$ \\
\hline CHF 694,000 - CHF 1,310,000 & CHF 770,001 - CHF 1,386,000 & $0.15 \%$ \\
\hline CHF 1,310,001 - CHF 2,235,000 & CHF 1,386,000 - CHF 2,311,000 & $0.2 \%$ \\
\hline CHF 2,235,001 - CHF 3,158,000 & CHF 2,311,001 - CHF 3,235,000 & $0.25 \%$ \\
\hline CHF 3,158,001 - & CHF 3,235,000 - & $0.3 \%$ \\
\hline
\end{tabular}

Additionally, the municipalities in the canton of Zurich also levy a wealth tax, as a percentage of the cantonal wealth tax. The maximal wealth tax rates in the canton of Zurich amount to approx. $0.7 \%$.

\footnotetext{
${ }^{4}$ https://www.efv.admin.ch/efv/de/home/themen/finanzstatistik/uebersicht-staatsfinanzen.html.
} 
The canton with the lowest wealth tax rates in Switzerland is the canton of Nidwalden, where the wealth tax rate is uniformly $0.0665 \%$, except for at least $10 \%$ shareholdings in corporations where the wealth tax rate is $0.0532 \%$. The actual wealth tax rate, when the relevant cantonal wealth tax multiplier is also considered, amounts to approximately $0.1 \%$, depending on the respective municipality.

Where an individual owns two houses ${ }^{5}$, each worth (a) 500,000 Swiss francs, (b) 1 million Swiss francs, (c) 2 million Swiss francs, (d) 10 million Swiss francs or (e) 20 million Swiss francs, the tax liabilities in each canton would amount to:

\begin{tabular}{|l|l|l|l|}
\hline $\begin{array}{c}\text { Value of Houses/Canton } \\
\text { (Municipality) }\end{array}$ & \multicolumn{1}{|c|}{$\begin{array}{c}\text { Geneva } \\
\text { (Geneva) }\end{array}$} & $\begin{array}{c}\text { Zurich } \\
\text { (Zurich) }\end{array}$ & $\begin{array}{c}\text { Nidwalden } \\
\text { (Stans) }\end{array}$ \\
\hline (a) CHF 1m & CHF 5,455 & CHF 2,126 & CHF 1,328 \\
\hline (b) CHF 2m & CHF 14,340 & CHF 6,165 & CHF 2'605 \\
\hline (c) CHF 4m & CHF 34,174 & CHF 17,780 & CHF 5,160 \\
\hline (d) CHF 20m & CHF 195,447 & CHF 123,883 & CHF 25,600 \\
\hline (e) CHF 40m & CHF 397,040 & CHF 254,239 & CHF 51,150 \\
\hline
\end{tabular}

In the case that two individuals were married and each of them would own one house worth (a) 500,000 Swiss francs, (b) 1 million Swiss francs, (c) 2 million Swiss francs, (d) 10 million Swiss francs or (e) 20 million Swiss francs, the single (combined) tax burden of the married couple would amount to:

\begin{tabular}{|l|l|l|l|}
\hline \multicolumn{1}{|c|}{$\begin{array}{c}\text { Value of House/Canton } \\
\text { (Municipality) }\end{array}$} & \multicolumn{1}{|c|}{$\begin{array}{c}\text { Geneva7 } \\
\text { (Geneva) }\end{array}$} & $\begin{array}{c}\text { Nidwalden } \\
\text { Zurich (Zurich) }\end{array}$ & \multicolumn{1}{c|}{ (Stans) } \\
\hline (a) CHF 500,000 (CHF 1m) & $\begin{array}{l}\text { CHF 2,728 } \\
\text { (CHF 5,455) }\end{array}$ & $\begin{array}{l}\text { CHF 950 } \\
\text { (CHF 1,899) }\end{array}$ & $\begin{array}{l}\text { CHF 664 } \\
\text { (CHF 1,328) }\end{array}$ \\
\hline (b) CHF 1m (CHF 2m) & $\begin{array}{l}\text { CHF 7,170 } \\
\text { (CHF 14,340) }\end{array}$ & $\begin{array}{l}\text { CHF 2,928 } \\
\text { (CHF 5,856) }\end{array}$ & $\begin{array}{l}\text { CHF 1,303 } \\
\text { (CHF 2,605) }\end{array}$ \\
\hline (c) CHF 2m (CHF 4m) & $\begin{array}{l}\text { CHF 17,087 } \\
\text { (CHF 34,174) }\end{array}$ & $\begin{array}{l}\text { CHF 8,648 } \\
\text { (CHF 17,296) }\end{array}$ & $\begin{array}{l}\text { CHF 2,580 } \\
\text { (CHF 5,160) }\end{array}$ \\
\hline (d) CHF 10m (CHF 20m) & $\begin{array}{l}\text { CHF 97,724 } \\
\text { (CHF 195,447) }\end{array}$ & $\begin{array}{l}\text { CHF 61,191 } \\
\text { (CHF 122,381) }\end{array}$ & $\begin{array}{l}\text { CHF 12,800 } \\
\text { (CHF 25,600) }\end{array}$ \\
\hline (e) CHF 20m (CHF 40m) & $\begin{array}{l}\text { CHF 198,520 } \\
\text { (CHF 397,040) }\end{array}$ & $\begin{array}{l}\text { CHF 126,869 } \\
\text { (CHF 253,738) }\end{array}$ & $\begin{array}{l}\text { CHF 25,275 } \\
\text { (CHF 51,150) }\end{array}$ \\
\hline
\end{tabular}

\footnotetext{
${ }^{5}$ Since the wealth tax in principle applies uniformly to all types of assets and no special tax rates apply to different asset classes, the same tax amounts would be due in the case of investments in private trading companies, investment companies or quoted shares and securities. However, the investment in different asset classes may lead to different valuations of the equity invested. An exception applies in the canton of Nidwalden, where at least $10 \%$ shareholdings would be subject to a lower wealth tax rate.

${ }^{6}$ Where the tax shield applies, a taxpayer would effectively be subject to lower wealth tax rates.

${ }^{7}$ Where the tax shield applies, a taxpayer would effectively be subject to lower wealth tax rates.
} 